\title{
Performing Austria: Protesting the Musical Nation
}

\author{
Allyson Fiddler \\ Lancaster University \\ a.fiddler@lancaster.ac.uk
}

\begin{abstract}
The Austrian national elections of 1999 and the subsequent government formation in 2000 sparked a wave of protests, both at home and abroad, due to the inclusion of the extreme-right populist Freedom Party of Austria (FPÖ) into the coalition. This article examines a body of protest music (ranging from heavy metal, rock and punk, to mock-choral and microtonal) that came about between 1999 and 2004 as a direct response to the turn in Austrian politics towards the extreme right. In interrogating this protest music I discern an important and hitherto underresearched facet of identity-(de)construction in Austria's artistic self-expression. It suggests a highly politicized counter-image to the usual, musically inspired representations of Austria, the land more readily associated abroad with Mozart and Haydn, the Vienna boys' choir, waltzing and yodelling. The music here is interrogated for the textual and musical strategies it deploys, and the spaces and icons of protest performance are probed for their efficacy and for the political interventions that they engender.
\end{abstract}

Keywords: Protest Music, Austria, Far-Right Politics, Anti-Far-Right Politics.

\section{Music and national identity formation}

Music plays a pivotal role in Austria's representation of its national identity - both externally as well as internally (Bruckmüller 1996: 121). We need only think of the most recent Mozartjahr ("Mozart Year") celebrations of 2006 to commemorate the $250^{\text {th }}$ anniversary of Mozart's birth, and consider its targeted utilization as tourist attraction (Austria Press Agency: 2006). Michael Billig (2002: 8) shows that national identity "involves being situated physically, legally, socially, as well as emotionally". Musical practices can function as constitutive factors in situating the national subject. In this sense there are various, at times banal, musical routes through which Austria directs its national identity and marks itself as a musical state. With quality confectionary called Mozartkugel ("Mozart Pralines"), for example, and a globally broadcast New Year's Day concert by the Viennese Philharmonic Orchestra, as well as international tours by the renowned Vienna boys' choir, music is paramount to the marketing of Austria as a brand.

In popular cultural terms, the non-domestic mythmaking of Austria's image as a musical nation is still predominantly carried by association with the perennially popular film The Sound of Music (dir. Robert Wise, 1965) and by erroneous assumptions about the ubiquity of Austrian practices such as yodelling ${ }^{1}$ and waltzing. ${ }^{2}$ Mozart is just one of a long list of Austrian composers with whom the international classical music-listening public is familiar, but it would be fair to say that outside Austria one would have to search far and wide for recognition of Austrian pop music, with the possible exception of Falco, whose popular single, with the English title "Rock Me Amadeus" (1985), makes playful reference to Mozart in a German-language rap. 
In terms of attracting political awareness to the small but wealthy Republic of Austria, the 1999 general election was the most recent event to have drawn international attention, especially from other members of the E.U. The polls resulted in the extreme-right populist Freedom Party of Austria (Freiheitliche Partei Österreichs, or FPÖ) securing a record $26.9 \%$ of the vote and being sworn in to a coalition government with the Austrian People's Party (Österreichische Volkspartei, or ÖVP) in February 2000. The E.U. placed rather short-lived diplomatic sanctions on Austria at the time, pending an official report, which in the autumn of 2000 exonerated Austria and its political parties (Ahtisaari et al. 2000). Israel withdrew its ambassador between February 2000 and February 2004, and in 2000 the United States also temporarily recalled its ambassador for talks. The FPÖ's then leader, Jörg Haider, stood down as head of the party, thus allowing his deputy, Susanne Riess-Passer, to become deputy chancellor to the ÖVP head of state, Wolfgang Schüssel. In the wake of the election and the government's subsequent inauguration, a wave of protest activities ensued, including marches and demonstrations (taking place every Thursday for over two years), public speeches, graffiti actions and debates. There was a huge outpouring of cultural protest, too, in the form of music, poetry, films, short stories, installations and performances.

This article seeks to capture and analyse a moment in music-making in Austria when musicians of a wide range of backgrounds (but mostly popular musical) used their art to try to cut across the nationalist "song" being sung by the state and counter this with different melodies, different rhythms, and different messages of what it means to Austrian. It is beyond the confines of this article to chart the political statements and counter-statements of the period. Rick Kunn (2000) provides a summary from an international, socialist perspective, which can stand here as an indication of what the many protests were about. The government's objectives included "cutting immigration quotas [...], targeting illegal immigrants, discrimination in schools against children who do not speak German, [...] as well as standard conservative measures like further privatizations, cuts in health, education and welfare spending, greater outlays on defense, law and order" (Kuhn 2000 - original spelling). The endeavour here, in characterizing and discussing a range of musical contributions, is to bring knowledge of this less well-known music to a broader readership, and perhaps also to help to bring the sound of this music to a wider listening public. In so doing, I hope to draw attention to a genre of protest that ought to have a wider impact and to augment music history and scholarship. This is particularly necessary in the case of a country so readily associated with the dominant idiom of mainstream, classical music. Whereas Barbara Lebrun can attest, for example, to the "Frenchness" of protest and demonstrate the long heritage of musical protest forms in France, similar claims are difficult to make for Austria (Lebrun 2009: 2).

\section{The corpus: expectations and questions}

One might expect official, state-associated music to be used in the political parody of protest movements but the Austrian national anthem does not feature in any of the tracks and compositions that are discussed here. The national anthem is an element in a few of the short protest films, though, that were made around the time of, and in reaction to, the FPÖ-ÖVP coalition government (Fiddler 2012). Philip Tagg (2011) is doubtless right to encourage academic exploration of the interface between music and film studies in the pursuit of epistemological progress. Film soundtracks are nevertheless omitted from the present analysis in order to maintain a comparable focus on specific musical genres. One example here, however, should attest to the explosively political possibilities. The music in Bernadette Huber's short film Wie böse ist Österreich? (1999) ("How Angry is Austria?") could have been of shock value in its musical execution or use of lyrics; yet this is not the case. Instead, to an orchestral 
rendering of the Austrian anthem, "Land der Berge" (1947), Huber's close-up visuals show a miniature national flag being born out of a woman's vulva and the expected colours of red-white-red turning to blue-white-blue (blue being the colour of the Freedom Party). In this way, the film seems to suggests that the new-born Austria of February 2000 is innately rightist-populist, which is emphasized by a text that enjoins the viewer to "Informieren Sie sich. Wie böse ist Österreich?" ("Get yourself informed: How evil is Austria?").

A national anthem is an exceptional category of music, and does not sit easily with Tagg's proposition that, "it's almost as if not seeing the music prevents us from consciously acknowledging its existence as music' (2011: 12). Anthems tend to have a performative function - as part of the ceremonial process in awarding Olympic medals or perhaps in concluding university degree-awarding ceremonies. If Tagg talks of our "scopocentric need for visual concretion of what we hear in order to consciously register its existence and, consequently, its potential effects" (2011: 12) and intends this to refer to visuals that show music being physically made, then Huber's visuals in fact do something similar. They do not necessarily invite the listener-viewer to muse over the chord progressions, cadences or dynamics of Austria's hymn, but they certainly ask the audience to register how Austria performs itself (not just literally through music) and to consider the potential effects of its national executive's actions.

Connoisseurs of Austrian popular music might expect the particular genre of "Austropop" to have steered clear of political intervention. Sometimes deemed to be a pejorative marker for a particular kind of engineered sound and soft lyric, frequently with dialect lyrics or flavour (Larkey 1992), ${ }^{3}$ Austropop is not as uniformally anodyne as assumed. Christian Karner (2002) points out that Austropop has functioned as a "site of political resistance and medium of cultural critique" through the decades. Edward Larkey draws our attention, for example, to Hubert von Goisern's reworking of the Haydn-composed "Gott Erhalte" hymn for the Habsburg Emperor Franz II and locates Goisern's reworking ("Gott erhalts, 1994) as, in part, a protest against the anti-foreigner campaign of Jörg Haider's FPÖ in the run-up to the referendum on European Union accession in the early 1990s (Larkey 1999: 227).

The corpus, then (see discography), is an eclectic range of music that the author has assembled and sees as having common cause. It does not seek to be inclusive, nor has it been possible to quote from all of the materials listed here. The music referenced dates from on or around the time of the first FPÖ-ÖVP coalition of 20002003 or from the early period of the second FPÖ-ÖVP coalition (2003-2007). The better-known longstanding, rock and pop bands are represented, ranging from the heavy-metal style of Drahdiwaberl, the melodic, narrative-style Austro-pop of the legendary Wolfgang Ambros, Rainhard Fendrich and Georg Danzer, known collectively as Austria 3, and indeed the celebrated, satirical pop of the highly successful, Erste Allgemeine Verunsicherung. Independent Austrian punk, rock and hip-hop artists mentioned include Brambilla, Conny Chaos und die Retortenkinder, and Kaputtnicks, as well as a piece by the German punk band, Die Ärzte, and a re-release by left-wing British protest folk and rock group, Chumbawumba, who lend the Austrian protesters "prominente internationale Schützenhilfe" [prominent international support] (Zellhofer 2006). Some of the music discussed here was collected and aired as a retrospective by the radio station Radio Orange in 2004, coincidentally the first year of Austria's now annual Protest Songcontest event, ${ }^{4}$ which was inaugurated amongst the burgeoning of protest music as an art form in the early twenty-first century. The popular music corpus is augmented here by reference to mock-choral work by Performing Resistance, electronic music by British-Austrian collaboration FURT, and experimental, microtonal work by Austrian composer, Georg Friedrich Haas.

It is not possible, nor would it yield much to, establish the sales figures of these songs and use them as some kind of proof of the endorsement they have received. In any case, listeners and fans buy music for all sorts of reasons and not just as signs of 
political allegiance. Moreover, many of the protest songs were given away or were downloadable for free after their public airing at concerts or demos. Analysis of the music played and the frequency and medium of broadcast would, of course, be useful and interesting, but it is simply not possible to assemble such information. ${ }^{5}$ Instead, the tracks and compositions are interrogated for the various ways in which they express their counter-hegemonic messages and give musical form to political criticism of Austria around the turn of the millennium.

Here, I set aside the pessimistic view associated with Theodor W. Adorno, that, "far from challenging the system, most music is part of the system" (Duncombe 2002: 276). Instead, with Oliver Marchart it is possible to regard the musical protest practices as examples of Soundpolitisierung ("sonic politicization"). Marchart asserts that it is not the type of sound itself that is to be identified as subversive, but that sound or music functions as a medium through which a community can grow and express its sense of political awareness:

das Politische [wird] nicht mehr im Sound selbst, im Material (z. B. der Digitalität) oder in ihren angeblich demokratischen Produktionsbedingungen gesucht [...]. Man geht nicht mehr davon aus, daß elektronische Musik an sich subversiv oder fortschrittlich oder befreiend sei. [...] Vielmehr geht es darum, daß eine bestimmte Szene oder Community sich öffentlich der Opposition gegen eine Regierung anschließt und das mit den ihr zu Verfügung stehenden Mitteln demonstriert. Darin besteht ihr Politik-Werden. (Marchart 2001 - web source)

(the political is now no longer sought in the sound itself, in the materiality (for example, its digital form) or indeed in its supposedly democratic means of production. The premise is no longer one that assumes electronic music to be inherently subversive or progressive or liberating. [...] Rather, it is a matter of a specific scene or community publicly opposing a government and demonstrating this with the means that are at their disposal. This is what constitutes its politicization. $)^{6}$

Marchart maintains furthermore that at that juncture in time at least (that is to say, in $1999 / 2000$ shortly after the election shock), it was not a coherent set of political demands or position statements that was needed, but rather just one demand and that this boiled down to: "Keine Koalition mit dem Rassismus. Oder noch kürzer: Weg mit der Regierung" ("No coalition with racism. Or, even shorter: down with the government").

\section{Text messages}

As might be expected with a body of music that has been inspired by the same cause, it is possible to make some generalizations about the lyrics in this corpus. Predictably, many of the songs contain statements that denounce the new government and bear testament to the effect that the song-writer or singer did not vote for the FPÖ and does not hold with what the ÖVP-FPÖ coalition is deemed to stand for. The perceived xenophobia and anti-immigration stance of the FPÖ comes in for criticism as do the planned reductions in welfare, cuts to the arts, and the proscriptive measures of the public media. The broad sentiments or indeed the verbatim statements made by politicians (of either coalition party) also feature in many of the tracks analysed here.

In the year 2000, hip-hop band Kaputtnicks rap their own Brief an den Kanzler ("Letter to the Chancellor"):

Ich sag nur "Gratishormone" oder "Stop der Überfremdung",

für nachträgliche Entschuldigungen keinerlei Verwendung.

... Doch 60 Jahre der Verdrängung reichen offenbar aus,

die neue Rechte ist gekommen, und sie sehnt sich nach Applaus.

("I'll just mention "free fertility drugs" or "stop the over-foreignization"

We've no use for belated apologies 
... It seems 60 years of repression just aren't enough

The new Right has arrived and is seeking approval.")

This rap is comparable to how an essayist might write an essay and make a speech, a writer or intellectual might write a public letter of protest to the politicians (and they did by the score at the time - we think of Peter Turrini, Marlene Streeruwitz, Doron Rabinovici, Elfriede Jelinek and many more). Austrians and Austria-watchers will recognize the FPÖ slogan Stop der Überfremdung ("Stop over-foreignization") and the controversial campaign by the then deputy leader of the FPÖ, Thomas Prinzhorn, who complained in 1999 that fertility treatment for immigrants was being funded by the Austrian state (Eidlhuber 2000).

As in other forms of artistic protest against the Austrian coalition government of 2000, there are direct attacks on the then party leaders, Jörg Haider and Wolfgang Schüssel. Other politicians also attract the opprobrium of the music scene. Foreign secretary Benita Ferrero-Waldner (ÖVP) or finance minister Karlheinz Grasser (FPÖ) are two further examples. In the number "B.E.N.I.T.A", by punk band Brambilla (2002), the foreign secretary's smile functions like the Cheshire cat's smile, ubiquitous and immutable. Metonymically, the smile stands for the politician but also suggests that the Austrian government's approach is one of smugness and superficiality. FerreroWaldner was alleged to have misled the media and the Genoese police and to have made little diplomatic effort to secure the release of seventeen Austrian protesters against the G8 whose guilt she implied, claiming that they were already known to Austrian police, or "amtsbekannt" (Foltin 2004: 264): "Da darf man sich nicht wundern/ Das Totschlagargument 'amtsbekannt'/ Und in den Interviewpausen/ Kann dieses Lächeln wirklich ehrlich sein?" ("Can we really be surprised?/ The killer argument 'already known to the authorities'/ And in the gaps between interviews / Can that smile really be sincere?"). The punk band Conny Chaos und die Retortenkinder pillory two other politicians, by implication if not by explicit name, in the number "KHG" (2004; probably named after Karl-Heinz Grasser, the FPÖ Minister of Finance in the 20002004 regime) and satirize the "tax amnesty" that he wanted to introduce to allow tax defaulters to pay missing taxes anonymously; ${ }^{7}$ and in the track, "Lisi Gehrer" (2004), the eponymous ÖVP politician Elisabeth Gehrer's 2003 criticism of young Austrians too busy partying to settle and have children forms the background to the singer's heavily ironic narrative about refusing the advances of a joint-smoking "Lisi Gehrer" at a party.

Much as in a roman à clef, there are songs that name no names but where the intended object of attack or satire is very easily decodable. When German punk band Die Ärzte sing in "Halsabschneider" $(2000)^{8}$ from the perspective of God looking down on the world and musing that he hasn't done a bad job, the "Arschloch" ("Arsehole") whose existence he bemoans in Austria, and rhymes with "immer noch", is not expressly named as Jörg Haider. This is, nevertheless, the equation the listener is invited to make. At 1'29", the track is very short. Together with its simple, clearly audible lyrics and melodic guitar line and occasional "ah-ing" backing vocals, the laconic message, "aber leider gibt's in Österreich ein Arschloch/ Immer noch" ("Regrettably, there's still an arsehole in Austria") is in sharp contrast to the angry style of the Kapputtnicks (above) but nonetheless emphatic in suggesting the reprehensibility of the "arsehole" it lampoons.

\section{Sampling and Plundering}

One of the common aesthetic devices in this corpus right across the spectrum of musical genres is the use of what we could term textual leitmotifs or recurring themes. In the song-texts as indeed in the literary materials of Austrian turn-of-the-millennium protest (in dramas by Elfriede Jelinek and Antonio Fian, or in films by Walter Wippersberg and others) well-known public remarks by politicians are embedded into the texture of the artistic work. Stefan Weber, lead singer of the heavy-metal band Drahdiwaberl, uses the first-person plural to denote himself and fellow band members 
with humorous intent as all those forces that Chancellor Wolfgang Schüssel, his government and the pro-coalition media have decried as being behind the democratic protests against the new coalition government, that is to say Anarcho-chaoten ("rowdy anarchists"), Stalinisten, and die Internet-generation. The backing singers' lyrics in the protest song "Torte statt Worte" (2000) acknowledge the irony that Drahdiwaberl's "best lines" are attributable to Wolf Martin and the pseudonymous Staberl, two troublestirring Austrian journalists who wrote for the arch right-wing tabloid Die Krone. The well-known band Erste Allgemeine Verunsicherung (EAV, formed in 1977 and regularly successfully charting in Austria) has made a living for nearly four decades out of comicsatirical music-writing. The band has enjoyed thirteen top-ten singles, with its most successful track staying in the charts for twenty-two weeks. The track "Valerie, Valera: Haiders Sprung in seiner Schüssel" (2000) uses spoken inserts between the sung verses and choruses. In a reasonably good imitation of Haider's regionally-inflected German, a voice quotes verbatim the infamous and begrudging elucidation Haider offered to a journalist who probed his use of euphemistic terms to describe Nazi atrocities: "Im dritten Reich gab es Vorfälle, die nicht entschuldbar waren. Wenn Sie so wollen, war es halt Massenmord" ("In the Third Reich there were incidents that were unforgivable. If you like, yes, it was mass murder") ("Valerie, Valera" 2000; Czernin 2000: 15-17). There is also an element of musical allusion or intertextuality in EAV's piece. The song obviously references "The Happy Wanderer" (Friedrich-Wilhelm Möller, 1953) in the hikers' refrain of "Falderie/Faldera" and nods to the "music" of Austria's football terraces with the insert of "immer wieder, immer wieder, immer wieder Austria" ("Austria, again and again").

The item which best exemplifies the use of musical intertexts is the composition, "Volksmusik" (2002), by Richard Barrett and Paul Obermayer. The two artists are the basis of a collaboration called "FURT" which mostly performs semi-improvised electronic music. Barrett and Obermayer contemplated declining an invitation to appear in Vienna during 2000 (as many artists and organizations did at the time), but instead offered this pre-recorded piece "created specifically for this concert, in solidarity with the resistance against Austrian neofascism" (Lepuschitz 2000) to a festival at the Sammlung Essl near Vienna. "Volksmusik" is a fifteen-minute-long composition, which adopts different techniques to the duo's live performances, with the use of what they have called "plunderphonics", following John Oswald's term (1986):

The point of "plunderphonics" seems to be that the found sounds are placed in quotation marks, so that the listener is supposed to recognise, if not their exact origin, then a sense of their cultural embeddedness, and thus their "difference" from the aesthetic intent of the music of which they form part and which is intended to be understood as "subverting" them, by removing them from their original context and placing them in one which contradicts their original (most often commercial) function. This isn't what FURT is trying to do, although we have made excursions in that direction (most obviously in Volksmusik, on the defekt $C D$ ), and of course we are aware that sound-materials do have a "double life" (as "pure" sonic events but also as connotation). (FURT in Bianchi, 2005)

FURT do not list their sampled sources. Hannah Skrinar, however, detects "shades of Wagner or Strauss; hard to tell which exactly" (Skrinar, 2004). The recording seems to suggest the use of Austrian musical samples in the form of highly slowed-down Bruckner and certainly a rendition of Lehár's "Dein ist mein ganzes Herz" (at 1' 53"). ${ }^{9}$ Charlie Chaplin is also excerpted from the film The Great Dictator (dir. Charles Chaplin 1940). Chaplin's nonsense German words are fragmented, sampled and regularly repeated ("Hai - der - Hai - der - Hai - der"; at 4' 21") in one particular section, with the effect that the repeated nonsense word sounds like it refers to the politician Jörg Haider. Here, FURT practises a kind of musical mise-en-abyme as it ironizes and samples Chaplin, who earlier parodied Hitler-noises. "Volksmusik" finishes with the eerie, distorted tones of what sounds like an alpine horn (14'45") or possibly slowed down yodelling (e.g. 10'29" or 13'27'), just as it begins with a standard 2/4-time 
"oompah" brass band music. The musical phrase is then interrupted and repeated over and over like a broken record or scratched CD to frustrate our sense of musical closure and to question the connotations of what might be read as volkstümlich ("folksy") in the case of the alpine horn/yodelling idiom, or as military-style nationalist music in the case of the brass marching music. Philip Bohlman explains that "nationalist music [...] frequently turns to folk music, laying claim to its authenticity" (Bohlman 2004: 83), and Austria is no exception in this regard. ${ }^{10}$

With FURT's own manifesto in mind, the duo are clearly subverting the romantic idiom as well as the local Volksmusik genre. "Volksmusik" (2002) thus functions very differently to most of the music discussed here. Music that has been played at protest concerts or danced to at demonstrations (see below) might well foster "muscular" or indeed "sonic" bonding following Thomas Turino's suggested coinage: "William H. McNeill (1995) suggests the term "muscular bonding" for the sense of oneness derived from marching or dancing together in close synchrony; we might add the term "sonic bonding" when this occurs through music making" (Turino 2008: 3, note 2). FURT's logic questions and frustrates easy bonding or identification by continually subverting musical idiom and by requiring an active listener to decode and decipher the music and its messages. FURT's "Volksmusik" represents a somewhat paradoxical musical example, then. In musical terms, it does not promote the sense of "wholeness" and "integration" which, theorists argue, can be facilitated by artistic communication (Bateson 1972, in Turino 2008: 3-4). "Volksmusik" cannot be easily identified with, hummed along to or otherwise participated in via dance, or by anticipation of its harmonic progression. Nevertheless, the intellectual challenge of the piece with its resistant music and political appeal does precisely call out for common identification, if not by listeners' common experience of being caught up in the music then certainly through a process of allegiance-building or common cause with the political intent of the composition and its performance.

\section{Do actions speak louder than (song) words?}

"Pop-music", according to socio-linguist Peter Trudgill, "is a field where language is especially socially symbolic, and typically low in communicative function, high on the phatic and self-expressive" (cited in Frith, 1996: 168). This affective nature of popular music (Duncombe 2002; Thompson and Biddle 2013) means that lyrics do not generally function to command or indeed to initiate action and are not generally received by listeners in this way. This may be the reason why British band Chumbawamba did not attract legal claims of incitement for their memorable chant, "Give the fascist man a gunshot" in the track "Enough is Enough (Kick it Over)" when the bullet's target is easily decodable - in their post-2000 iterations of the song - as Jörg Haider. The single was remixed and re-released as a single CD in 2000 and given away at concerts in Austria as "a gesture of solidarity towards Austrian anti-fascists" (NME 2000). The fact that the lyrics are in English, and thus not so immediately comprehensible to a German-speaking audience, is not in itself grounds for the lack of litigious attention. German-speaking musicians quite commonly employ phrases in English. The Kaputtnicks' rap is predominantly in German, but they reserve a line or two of the choicest language to be rapped in English: "yeah we live in Austria, but fuck this government" (Kaputtnicks 2000).

Austrian musicians were not entirely free from legal pressures, however. Some Austrian political leaders, the FPÖ and ÖVP politicians who were the target of song lyrics during this period, for example, sought to mete out punishment against compatriots who had offended them. In the present context, we can point to threatened legal action by the FPÖ which forced hard-rock band Drahdiwaberl to remove two planned tracks, "Schulterschluss" and "Stecker raus und "Tschüsserl" from its Torte statt Worte CD (raw 2000). Similarly, Klaus Eberhartinger of Erste allgemeine Verunsicherung found that although Haider did not take legal action against him for 
"Valerie, Valera", the public broadcasting service, ORF (Österreichischer Rundfunk), would not play the track. This is tantamount to a kind of state-instigated censorship, with the national public radio station intervening and determining what the state's citizens should not hear (laut.de 2000).

Drahdiwaberl's "Torte statt Worte" ("Cream Pies, not Words") is an ironic call to arms by wielding cakes, even if it otherwise tries to counter the idea of song-text as affective rather than instructive in nature. This number was dubbed the "Urhymne aller Widerstandsnummer" (the founding resistance song) by Radio Orange DJs (Zellhofer 2006), whose retrospective of millennial protest songs was aired on 13 December 2006. Throwing cream cakes is quite a novel mode of protest in Austria, and indeed in the UK, neither of which can point to "custard pie throwing - as a political art form" in the manner exemplified by Belgian activist Noel Godin (Stoddard 2011). The DJs even passed comment on how the verb, "torten", had only recently been coined. The words of lead vocalist and founder member Stefan Weber can, then, be read as a kind of homage to those who don't just talk (or sing words, perhaps, like his band and others) but instead take action. Reputedly the first pie-in-the-face of the resistance campaign, and the catalyst for this track, was in April 2000 and was directed at Hilmar Kabas, the leader of the Viennese branch of the FPÖ (Weidinger 2001).

The problem with throwing lyrics - as opposed to throwing pies (assuming that these hit their targets) - is that their intended meanings are subject to slippage or to misunderstanding. Frith writes of the Republican party's attempt to hijack Bruce Springsteen's "Born in the USA" in 1984. He points out how the latter laid claim to a certain sort of veteran soldiers' experience and anti-Vietnam war stance, whereas the sheer impact of the music was very different. "Born in the USA!'”, he says, "[is] a musical phrase which is, in rock convention (its texture, its rhythmic relentlessness, its lift), not bitter but triumphant. In other words, for a rock listener what comes across from this song is not the intended irony of the chorus line, but its pride and assertiveness" (Frith 1996: 165). Something similar could be said for the lyric, "I am from Austria" (original title), re-released in 2000 (originally Reinhard Fendrich 1990, but re-issued in 1998 by Austria 3, the collaboration of three big names in Austropop, namely Reinhard Fendrich, Wolfgang Ambros and Georg Danzer). Karner argues persuasively that the lyrics have been somewhat overlooked and that the song has been misunderstood as "a concession to the narrow, ethnic nationalism usually associated with Haider" (Karner 2002: 14). As with the Springsteen example, the lyricist's intention has not prevented the titular refrain being repeated or appropriated as a badge of national pride regardless of political persuasion. The song "I bin aus Österreich" ("I am from Austria") by STS, bearing an Austrian dialect title with the same meaning, must, on the other hand, be understood as a deliberate work of political resistance, with its inclusive lyrics and articulating "a counter-hegemonic discourse challenging the premises of an ethnic nationalism and replacing it with a more open, multicultural conception of Austrian society" (Karner 2002: par. 4.8).

The question of which kind of lyrics we might find ourselves singing along to, is of interest here. Frith notes on singing from an everyday perspective that "most people are happier to talk in public than to sing", and that,

whatever the sociological reasons, the fact is that most of us experience singing (unlike speaking) as a performance... A performance in two respects: singing draws a different sort of attention to the words ...; and it draws a different sort of attention to the singer, hence the embarrassment. Singing seems to be self-revealing in a way that speaking is not. (Frith 1996: 172)

We should consider, however, whether it is not, in fact, the reverse that holds true for crowd singing. Frith's argument might only apply to solo performance. My supposition is that most of us are more likely to join in singing (or chanting) resistant texts as a 
group than we are to solo-compose or to "speak" resistant text on our own, to voice resistant contributions at a political meeting, say, or a rally.

\section{Uses of music in the 1999/2000 protests}

With regards the performative uses of music and sound in the context of the anticoalition demonstrations, a good example of demonstrators using art to effect protest is the group Performing Resistance who sang, or perhaps better, "intoned" their performance live as protest in the streets, often as part of the weekly Thursday demonstrations. The group describes one piece as a "Chor der Nachbeter mit basso obstinato" (2000; "Copycats' Chorus with Obstinate Bass"), ${ }^{11}$ and it, too, employs the device of verbatim replication of quotations by Jörg Haider and other political figures (see discussion of quotation and of plunderphonics above). Although the chorus provides a confirmatory echo of the prayer leader's incantations of objectionable FPÖ statements, the "obstinate" bass expresses quizzical disbelief as first one voice then a cacophonous mélange of voices ask, rhetorically, "Was hat er gesagt?" ("What did he say?") at different times and at different pitches. The result is that the seamless performance of the calls-and-responses is interrupted and called into doubt as the vehemence of the obstinate voices stops the procession of supplicants (Delle Karth 2002: 153). Thus, the performance of blind musical obedience (responding in unison to the call) is ruptured and the group thereby suggest or invoke a breaking-up of uniform, far-right thinking.

The first verse of the performance piece begins with the group's "performance" of former deputy-mayor of Klagenfurt, Reinhard Gaugg's 1993 interview answer to the question "Was sagt Innen das Wort "Nazi"?" ("What does the word "Nazi" say to you?"). His answer was: "neu - attraktiv - zielstrebig [determined] - ideenreich [imaginative]" (ORF 2006). The musical genre is chosen deliberately. In deploying a choir, or chorus, the group ironically replicates the group of acolytes and obedient voices that surrounded Jörg Haider, but then breaks down that choric unison to destroy the conviction that such ideology can speak with one voice. The piece thus performs a kind of musical destruction of the FPÖ's "liturgy".

In Music as Social Life, Thomas Turino draws our attention to the context in which art is performed and builds on the notion that, "the arts are founded on the interplay of the Possible and the Actual and can awaken us from habit. The arts - music, dance, rituals, plays, movies, paintings, poems, stories - are a type of framed activity where it is expected that the imagination and new possibilities will be given special license" (Turino 2008: 17-18). The interesting thing about some protest art and music (and some kinds of performance art and installation) is that it bursts the expected or normally required frames or appropriates the "wrong" frame, just like the above parodic chorus example bursts the expected call-and-response normally contained within the church. The frame is different for the texts of projectionist-artist Julia Zdarsky (2000) who beamed her texts onto the wall of the Kanzleramt or for film-maker Frederick Baker, who projected images onto the backs of policemen during the Thursday demonstrations (Baker 2007). It is different, too, for the Volkstänzer ("folk dancers"), who brought dance out into the streets. In Western Europe, dance is most often an indoor, and usually a fixed-location activity, sometimes for participation and sometimes for show.

The source of music does not have to be contained in these days of hyperportability, however, making its "frame" more mobile than ever before. Frith has characterized dance as "willed movement", qualifying it further as "unnecessary movement, an end in itself rather than a means to another end (like walking to the store for milk or passing the ball to the inside right)" (2008: 221). Strictly speaking, there are dances - such as the toyi-toyi in South Africa, say - that are an integral part of political expression, that is, they are indeed not performed as an end in themselves but rather as part of the means of effecting protest. The political act of the Viennese Volkstänzer 
("folk dancers") in 2000 and beyond was to make dance a political vehicle, just as the Thursday demonstrators made their weekly walks a subversive act and not just a keepfit exercise or a mode of self-transportation. Whereas one might normally understand a folk dance to be part of a folkloristic ritual or traditional cultural practice, the group of people who gathered in public locations such as in front of the opera house (Baker and Boyer, 2002: illustration no. 44) met in order to make a noise and to dance the people's dance of protest, and precisely not a twee rendition of something involving Lederhosen and Dirndl. ${ }^{12}$ There is, thus, no specific protest music or dance type associated with this instance of protest (though the folk dance genre is implicitly denigrated by the group's ironic name). As a protest activity symbiotically linked to music, the Volkstanz invitation or "call to dance" saw a proliferation of different DJs, bands, hip-hop artists, orchestras and groups leaving the usual urban club scene and taking to the streets under the banner of dancing for dissolution (of the government), or "Abtanzen für Abdanken" (volkstanz.net 2000).

Ballroom dancing - waltzing in particular - is the symbolic dance of social power in Austria, due to its ready association with the social occasions of high society. ${ }^{13}$ The annual Wiener Staatsopernball ("state opera ball in Vienna") is one such society event, attended by celebrities and by the upper echelons of society. It is unsurprisingly also the locus for political and social protest groups, and protests have been staged outside the opera house on the evening of the ball through the decades and in the service of different causes. During the period in question, the protest was anti-regime, but the FPÖ and others have been known to use their own annual ball to make political statements, too. A good case in point is the the 2012 ball of the Wiener Korporationsring, an organization of alumni student members from what are known as "fencing corporations" ("fechtende Verbindungen" or "Burschenschaften" in Austria). The organization's choice to hold its ball on Holocaust memorial day was deemed a huge offence and statements by the current leader of the FPÖ, H.C. Strache, served to inflame the situation. Strache likened the experience of the ball invitees, being subjected to protests, as tantamount to the persecution of the Jews (Kahlweit 2012). There is not space to discuss here the notorious "raps" performed by H. C. Strache, nor indeed the focused campaign amongst the Austrian rapping community, who rallied to demonstrate to the politician their disgust and anger at his - admittedly very poor appropriation of their musical genre to express his nationalist, anti-immigrant policies (see Norman, 2006).

\section{“Key" Change and Conclusion}

The most ubiquitous way in which sonic protest made itself heard in the early days of the protests was not in the form of fully-fledged words or music but in the iconic use of sound. Jacques Attali's late-1970s' investigation starts with the concept of "noise" per se, and it seems fertile to apply this to the noises of protest. Attali advises that:

we must learn to judge a society more by its sounds, by its art, and by its festivals, than by its statistics. By listening to noise, we can better understand where the folly of men and their calculations is leading us, and what hopes it is still possible to have" (Attali 1985: 3)

One of the loudest, "unscored", noises during the Austrian protests was produced by the jangling of keys. In semiotic terms, this musical "sign" takes on iconic significance. "Iconic processes are fundamental to musical meaning in terms of style [...] recognition and are basic to our cultural classification of most things", Turino explains (2008: 6). He then furnishes examples along the lines of how we might come to associate the sound of kettle drums with the roll of thunder or with cannons, according to a larger context, such as our geographical, historical or cultural origins. It is not the musical colour or timbre of key-shaking, however, that is iconic or suggestive, say, of the would-be Chancellor's character. Rather, the near homonym of "Schüssel" (the Chancellor's 
surname) and "Schlüssel" (key or keys) meant that an obvious protest became the jangling of key fobs to indicate "kein Schlüssel für Schüssel" (no key for Schlüssel) as protesters demanded that his administration should not be let in to the chancellory (trend 2000). Since, as Turino suggests, "most people the world over connect the majority of musical signs to their objects either through resemblances or through cooccurence" (Turino 2008: 14), the key jangling becomes an iconic sound during this period, the performance of which is instantly recognisable as a political demand. In the music of protest, the other meaning of "Schüssel" (bowl) becomes useful to comic activists such as Erste allgemeine Verunsicherung who impugn the incoming Chancellor's sanity and imply that he has lost his marbles, or rather, in German, that he has a leak in his bowl, "einen Sprung in der Schüssel" (Erste allgemeine Verunsicherung 2000).

Wolfgang Schüssel's chancellorship of Austria in fact continued until 2007, with the chancellor holding on to his keys over a further national election in November 2002 and remaining in coalition with the FPÖ. ${ }^{14}$ Given the longevity of the coalitions of centre right and populist right in twenty-first century Austria to date and the electoral share garnered by parties of the far right, observers might find themselves asking whether all of this singing and dancing was not a waste of time and effort, all "in vain", as the 2000 composition by microtonal Austrian composer Georg Friedrich Haas called his sixtythree-minute piece (Haas 2004). After a 2009 concert in the U.S., Time Out New York wrote that Haas "spoke of having channeled his frustration and anger into the composition of that turbulent piece, after his nation voted a far-right government into power in 2000" (Lockwood, 2009). The combined far-right election share in 2008 was around $27 \%$, that is to say higher than the ÖVP and second only to the winning socialist party (SPÖ). It is tempting to be pessimistic, therefore, as to the effectiveness of protest against the far-right or indeed to conclude that Austria is currently very receptive to the political arguments of the far-right. In his history of social movements in Austria, Robert Foltin observes of the demonstrations and protests of 2000 first of all that, "die breiteste Bewegung, die es je in Österreich gegeben hat, scheint praktisch nichts bewirkt zu haben" (the broadest [civil] movement that there has even been in Austria seems to have achieved almost nothing). Foltin does, however, conclude that all of the protest contributions have indeed played their part in forging a greater sense of civil society in Austria. Future "revolutionary" projects will be able to pick up, he feels, where the millennial protests left off (Foltin 2004: 261).

For the author of this article, there seems little evidence to suggest that Foltin is correct. For example, Austria's "Protest Songcontest" celebrates its tenth anniversary in 2013. One might look at this fact and conclude that protest music has been institutionalized, perhaps even neutralized in Austria, in view of its celebration in an organized, annual competition. The contest was won in February 2013 not by the reallife asylum-seeking protesters engaged in a sit-in in Vienna's Votive Church but by Benedikta Manzano with a satirical song pleading for more understanding and sympathy for the financial markets ("Mehr Mitgefühl für Märkte" 2013). The group Anstaltskinda aka Kapitano Chaotico as well as the group members of Refugee Protest Camp Vienna used their contribution, "We love Vienna/Je t'aime Vienne" (2013) to get their protest across to a much wider public and to make a direct appeal to the Austrian government. Their song's introductory words state: "die Regierung hört unsere Argumente nicht. Vielleicht hört sie unsere Musik" (refugees of the vienna refugee camp, 2013; "the government isn't listening to our arguments, perhaps it'll listen to our music"). That the jury decided in favour of the musically more polished Manzano was a great disappointment to many commentators. The often controversial music journalist Martin Blumenau, for example, talks of the shame of hearing the lead singer apologize for the weakness of his vocal performance in view of his ongoing hunger-strike. Blumenau laments the jury's recourse to the criteria of musical skill and execution and feels that the refugees are the truer artists for their rawer, more impactful and honest 
message. Blumenau (2013) emphasizes that "Die Künstler werden uns nicht retten. Die Musiker am allerwenigsten" ("artists will not save us, least of all the musicians").

It is true that the answer to political and social progress lies mostly with legislators, politicians and those with executive power. However, opinions and social practices are subject to influence not just by those in public office but by arts practitioners, musicmakers, novelists and film-makers too. Austria has given renewed attention to music as a vehicle for political message-making in the course of the last ten to fifteen years. The particular examples of music discussed here are by nature rhetorical or programmatic in their intent, and it would not do to extrapolate from this sample and make assertions about changes in Austrian music tout court. Under scrutiny is, nevertheless, a signficant body of music in and about Austria that is contesting what the nation stands for at a particular moment in time, that is, in the wake of the 1999 elections and beyond. Austrian musicians are using their medium in part to deconstruct musical paradigms but also to make political arguments heard. To an audience more usually accustomed to associating Austria with the classical idiom, there is undoubtedly a great deal more to Austria's music than usually meets the international ear.

\section{Endnotes}

${ }^{1}$ Yodelling is a traditional Alpine style of using the singing voice by fluctuating rapidly between normal chest voice and falsetto.

${ }^{2}$ The waltz is a ballroom dance historically associated with Vienna.

${ }^{3}$ Larkey (1992) documents a wide range of potential characteristics of Austropop and responses to the term in his very full exploration of this genre.

${ }^{4}$ Protest Songcontest information: http://www.protestsongcontest.net/

${ }^{5}$ Advice was sought from both the Austrian Popular Music Archive (Verein SR-Archiv österreichischer Popularmusik; http://www.sra.at/) and the Austrian Charts organization (http://austriancharts.at/).

${ }^{6}$ All translations by the author unless otherwise indicated.

${ }^{7}$ Grasser continues to be a ripe subject for musical satire. See the recent song, "KarlHeinz" by Christoph \& Lollo (2011).

${ }^{8}$ This single by the still current and highly successful German rock band is from an album that reached fifth place in the German charts and twelfth in the Austrian charts in 2000.

${ }^{9}$ I should like to thank to Martin Iddon for first drawing my attention to this item and for his assistance in interpreting it.

${ }^{10}$ As Bohlman spells out, the development of folk music in Austria has, however, absorbed the multicultural influences of the former Habsburg empire. Musical traditions from Austria's Imperial past were put to political effect following the fall of the Iron Curtain, to present a new sense of Austria's importance within Central Europe (Bohlman, 2004: 163).

${ }^{11}$ Basso obstinato is a word play on the Italian musicological term basso ostinato ("stubborn, or obstinate, bass").

${ }^{12}$ Lederhosen (knee-length leather trousers) and Dirndl (an outfit of skirt, apron, and bodiced blouse) are items of traditional Austrian costume.

${ }^{13}$ Nineteenth-century society was initially scandalized by the introduction of such close couple dancing. For a nuanced reading of the waltz, including questions of status and economic impact, see Knowles, 2009.

${ }^{14}$ In 2005, the coalition mutated into one between the ÖVP and the Bündnis Zukunft Österreichs (BZÖ; Alliance for the Future of Austria), a new splinter party forged by 
Jörg Haider and other leading lights of the FPÖ. Jörg Haider died in a car accident in October 2008.

\section{References}

\section{Bibliography}

Ahtisaari, M., Frowein, J. and Oreja, M. (2000) 'Report'. Adopted in Paris, 8 September 2000.http://www2.ohchr.org/english/bodies/hrc/docs/ngos/HOSI-1.pdf. Accessed 28 February 2013.

Attali, J. (1985) Noise: The Political Economy of Music. Transl. Brian Massumi. Manchester, Manchester University Press. First publ. Bruits: essai sur l'économie de la musique. 1977. Paris, Presses Universitaires de France.

Austria Press Agency (2006) “Mozart 2006” als Gästemagnet für Österreichs Tourismus". http://www.ots.at/presseaussendung/OTS 20031117 OTS0077/mozart-2006-alsgaestemagnet-fuer-oesterreichs-tourismus. Accessed: 28 February 2013.

Baker, F. and Boyer, E., Ed. (2002) Wiener Wandertage: eine Dokumentation. Vienna, Wieser, 2002.

Baker, F. (2007) The Art of Projectionism. Vienna, Czernin Verlag.

Bateson, G. (1972) Steps to an Ecology of Mind: Collected Essays in Anthropology, Psychiatry, Evolution, and Epistemology. St Albans, Australia. (Quoted in Turino 2008).

Bianchi, S. I. (2005) Blow Up (June). Reproduced at furtlogic.com, http://furtlogic.com/node/16. Accessed 28 February 2013.

Billig, M. (2002) Banal Nationalism. London, Sage.

Blumenau, M. (2013) "Geschichten aus dem wirklichen Leben". 13 Feb. http://fm4.orf.at/stories/1712739/. Accessed 28 February 2013.

Bohlman, P. V. (2004) The Music of European Nationalism: Cultural Identity and Modern History. ABC-CLIO Ltd.

Bruckmüller, E. (1996) Nation Österreich: kulturelles Bewusstsein und gesellschaftlichpolitische Prozesse. Vienna, Böhlau.

Czernin, H.., Ed. (2000) Wofür ich mich meinetwegen entschuldige: Haider, beim Wort genommen. Vienna, Czernin.

Delle Karth, N. (2002) "Chor der Nachbeter mit basso obstinato". In Frederick Baker and Elisabeth Boyer, Eds. Wiener Wandertage: eine Dokumentation. Vienna, Wieser: 151-58.

Duncombe, S. (2002) Introduction to "Adorno, On the Fetish-Character in Music and the Regression of Listening". In Stephen Duncombe, Ed. Cultural Resistance Reader,.London: Verso: 275-302.

Eidlhuber, M. (2000) "Du sollst recherchieren! Die gängigen Vorwürfe an Haider und was Sie darüber wissen sollten". Die Zeit. 17 February: 1-5 (4), http://www.zeit.de/2000/08/200008.reden tabelle 2 .xml/seite-4. Accessed 28 February 2013.

Fiddler, A. (2012) "Lights, camera,... protest! Austrian film-makers and the extreme right." Journal of European Popular Culture. 2 (1): 5-18.

http://dx.doi.org/10.1386/jepc.2.1.5 1.

Foltin, R. (2004). Und wir bewegen uns doch: Soziale Bewegungen in Österreich. Vienna, Edition Grundrisse. 
Frith, S. (1996) Performing Rites: On the Value of Popular Music. Cambridge, Mass: Harvard University Press.

Kahlweit, C-(2012) "FPÖ-Chef vergleicht Burschenschafter mit verfolgten Juden", Süddeutsche Zeitung. 31 Jan. http://www.sueddeutsche.de/politik/ball-des-wienerkorporationsrings-fpoe-chef-vergleicht-burschenschafter-mit-verfolgten-juden1.1271390 Accessed 28 February 2013.

Karner, C. (2002) “'Austro-Pop' since the 1980s: Two Case Studies of Cultural Critique and Counter-hegemonic Resistance", Sociological Research Online, 6 (4). http://dx.doi.org/10.5153/sro.654.

Kuhn, R. (2000) "The threat of fascism in Austria". Monthly Review. 52 (2) June: 21-35. Online at: http://www.anu.edu.au/polsci/rick/fascism-austria.htm. Accessed 19 July 2013.

Knowles, M. (2009) The Wicked Waltz and Other Scandalous Dances: Outrage at Couple Dancing in the 19th and Early 20th Centuries. Jefferson, N.C.: McFarland.

"Land der Berge" (1947) Text by Paula von Preradovic, with minor amendments in 2012. Music attributed to Wolfgang Amadeus Mozart or to Johann Baptist Holzer. http://www.bundeskanzleramt.at/site/5131/default.aspx. Accessed 28 February 2013.

Larkey, E. -

(1992) "Austropop: Popular Music and National Identity in Austria". Popular Music, 11 (2): 151-185

(1999) "Americanization, Cultural Change, and Austrian Identity". From World War to Waldheim. Ed. David F. Good and Ruth Wodak. New York, Berghahn: 210235.

Laut.de. (2000) "E.A.V.-Sänger beklagt Zensur durch die Medien”. 24 July. http://www.laut.de/Oesterreich/E.A.V.-Saenger-beklagt-Zensur-durch-dieMedien/24-07-2000. Accessed 28 February 2013.

Lebrun, B. (2009) Protest Music in France: Production, Identity and Performance. Farnham, Ashgate.

Lepuschitz, R. (2000). Transl Elfi Cagala, "[bracket] \#2: FURT", in: Almanach WIEN MODERN 2000. Ed. Berno Odo Polzer. Vienna, 2000). http://www.essl.museum/musik/archiv/bracket/furt.html. Accessed 28 February 2013.

Lockwood, A. (2009) "Discordant harmony: Ensemble Pi and Sarah Cahill examine political activism in music". http://www.timeout.com/newyork/operaclassical/discordant-harmony. Accessed 28 February 2013.

Marchart, O. (2001) "Was heißt Soundpolitisierung?", http://www.volkstanz.net/mind nut/01.htm. Accessed 28 February 2013.

McNeill, W. H. (1995) Keeping Together in Time: Dance and Drill in Human History. Cambridge, MA, Harvard University Press. (Quoted in Turino 2008).

NME (2000) "Download Chumbawamba track for free". (July 12). http://www.nme.com/news/chumbawamba/3836. Accessed 28 February 2013.

Norman, B. (2006) "The Politics of Austrian Hip-Hop: HC Strache's Xenophobia Gets Dissed", Colloquia Germanica, 39 (2): 209-30.

ORF (2006) "Der Schulterträger Haiders". http://newsv1.orf.at/060724-2006/. Accessed 28 February 2013.

Oswald, J. (1986) "Plunderphonics, or Audio Piracy as a Compositional Prerogative," Musicworks 34 (Spring): 5-8.

RAW (rosa antifa wien) (2000) "Newsletter boeses:oesterreich 1000". 6 October. 
http://raw.at/texte/gegenschwarzblau/newsletter-boeses-oesterreich-1000/. Accessed 28 February 2013.

Skrinar, H. (2003) "Compositional improvisation from the electroacoustic duo...., FURT Defekt Review, 17 January. http://www.bbc.co.uk/music/reviews/mpqv. Accessed 28 February 2013.

Stoddard, K. (2011) "Custard pie as political art form: 1998 profile of Noel Godin". Guardian. From the Archive Blog. http://www.guardian.co.uk/theguardian/from-thearchive-blog/2011/jul/19/archive-noel-godin-custard-pie. Accessed 28 February 2013.

Tagg, P. (2011) "Caught on the Back Foot: Epistemic Inertia and Visible Music", IASPM@Journal, vol. 2, Nos 1-2 . http://dx.doi.org/10.5429/2079-3871(2011)v2i1 2.2en

Thompson, M. and Biddle, I. (2013) "Introduction: Somewhere between the signifying and the sublime". In Marie Thompson and lan Biddle, Eds. Sound, Music, Affect: Theorizing Sonic Experience. London and New York, Bloomsbury.

trend (2000) "Die ersten sieben Tage: Aktionen Gegen Schwarzblau in Wien". http://www.trend.infopartisan.net/trd0200/t170200.html. Accessed 28 February 2013.

Turino, T.(2008) Music as Social Life: The Politics of Participation. Chicago, University of Chicago Press.

Volkstanz.net. (2000) "Abtanzen für Abdanken", http://www.action.at/network/?/cgibin/network/kategs.pl?art=organizations\&id=20. Accessed 28 February 2013.

Weidinger, K. (2001) "Widerstand im Mehlspeisland", http://www.kawei.at/site txt 2001.htm. Accessed 28 February 2013.

Zdarsky, J. (2000) "Zufallsindoktrinator". http://www.starskyprojections.com/page.php?id=3. Accessed 28 February 2013.

Zellhofer, M. (2006) "Steckt's den Kopf nicht in den Sand, das Zauberwort heißt Widerstand!". UNIQUE - Magazin der ÖH Uni Wien. No. 6.

\section{Discography}

Anstaltskinda aka Kapitano Chaotico and the refugees of the vienna refugee camp, (2013) http://refugeecampvienna.noblogs.org/post/2013/02/14/we-love-you-viennaje-taime-vienne-song-und-text-jetzt-online/. Accessed 28 February 2013.

Austria 3. (1998) "I am from Austria". Austria 3: Freunde. CD Single. Ariola, Austria. (Originally, Reinhard Fendrich. 1990. "I am from Austria". Ariola, Austria.)

Benedikta Manzano (2013). "Mehr Mitgefühl für Märkte". Available currently on YouTube at: http://www.youtube.com/watch?v=nbk5mJB4zww. Accessed 28 February 2013.

Brambilla (2002) "B.E.N.I.T.A." Little Terror Creek. Lunadiscs/Knallcore and Bloodshed 666, Austria.

Bruce Springsteen (1984) "Born in the USA", Columbia, USA.

Chor der Nachbeter mit basso obstinate (2000) "Politlitanei von Nicole Delle Karth", $A$ COLLAGE und Chor der Nachbeter mit basso obstinato. Gas, Austria. http://www.2gas.net/musikw.htm. Accessed 28 February 2013.

Christoph \& Lollo (2011) "Karl-Heinz". Tschuldigung. Wohnzimmer/Hoanzl, Austria.

Chumbawamba (2000) "Enough is Enough (Kick it Over)". Woodlands Studio, UK. Originally released 1993 as "Enough is Enough" by Chumbawamba and Credit to the Nation.

Conny Chaos und die Retortenkinder (2004) "Lisi Gehrer”. Broken Heart Records, 
Austria.

Conny Chaos und die Retortenkinder (2004) "KHG". Retorte Rockt! (4-Track DemoCD), Broken Heart Records, Austria.

Die Ärzte. "Halsabschneider". (2000) B side of Wie es geht. Single, Hot Action Records, Germany.

Drahdiwaberl (2000) "Torte statt Worte". Torte statt Worte. Drahdiwaberl Music, Austria.

Erste allgemeine Verunsicherung (2000) "Valerie, Valera". Promo Single CD. Blanko Musik, Germany.

Falco (1985) "Rock Me Amadeus", Falco 3, GiG Records, Austria.

Friedrich-Wilhelm Möller (1953) "The Happy Wanderer", (sung in German: "Der fröhliche Wanderer"). Parlaphone, United Kingdom.

FURT (2002) "Volksmusik”. defekt. Matchless Recordings, United Kingdom.

Haas, Georg Friedrich (2004) "in vain", in vain. Kairos, Austria [first performed 2000 at the Klangforum, Vienna].

Hubert von Goisern, und die Alpinkatzen (1994) "Gott erhalts". Omunduntn, Ariola, Austria.

Kaputtnicks (2000) "Brief an den Kanzler", Geco Tonwaren, Austria. See also http://www.youtube.com/watch?v=1tiZP5z99YI. Accessed 28 February 2013.

\section{Videography}

The Great Dictator (1940) Director: Charles Chaplin, Charles Chaplin Film Corporation. The Sound of Music (1965) Director: Robert Wise, Robert Wise Productions, Twentieth Century Fox Film Corporation.

Wie böse ist Österreich? (1999) Director: Bernadette Huber.

http://www.bernadettehuber.at/video.htm. Accessed 28 February 2013. 